\title{
Power Loss Reduction via Distributed Generation System Injected in a Radial Feeder
}

\author{
Irshad Hussain', Faizullah Khan ${ }^{2 a}$, Ishtiaq Ahmad ${ }^{2 b}$, Surat Khan ${ }^{2 c}$, Muhammad Saeed
}

RECEIVED ON 02.04.2019, ACCEPTED ON 03.03.2020

\begin{abstract}
The energy demand all over the world is increasing rapidly day by day. In traditional power systems, power plants are located far away from the consumer's premises. This in turn causes a substantial amount of power loss both in transmission and distribution. In general, distribution system has more losses than the losses occurred on the transmission side. It employs that there will be a significant difference between the generated power and the energy consumers that are (physically) far away from the generating stations. Therefore, the electric utilities always remain under stress due to such non negligible amount of losses which has a direct impact on financial management and efficiency of the power system as well. To address this issue different technique have been introduced to reduce line losses and to improve the efficiency. The best among these techniques is line loss reduction through Distributed Generation (DG) which is more effective than the other techniques. In this paper we have taken three $11 \mathrm{kV}$ feeders (located at Bannu) as a case study and for the prescribed technique an attempt has been made to increase the efficiency of a system by integrating different capacity of DG into a radial distribution feeder. The results have been analyzed mathematically, however Electrical Transient Analyzer Program (ETAP) simulator is used as a test bed. Finally, the obtained results are presented in tabular and graphical form in terms of clearly defined parameters.
\end{abstract}

Keywords: Distributed Generation, Ring feeder, ETAP, Power loss reduction

\section{INTRODUCTION}

For power companies to deliver electricity to users, they need to go through several stages. The first stage is the generation of power at large power stations. These power stations are located in uninhabited areas and far away from all charges to overcome environmental issues. The second phase is transmission; this is achieved with the help of various devices such as transformers, overhead transmission lines and subterranean cables. The third stage is the distribution system [1]. Due to low voltage and high current, the loss of the power distribution system is far greater than the transmission [2].
In an ideal situation, the total loss of real power in the energy system should be in the range of $3 \%$ to $6 \%$. In developed countries, the loss of real power in the energy systems is not more than $10 \%$. However, in developing countries, like Pakistan the loss of real power systems is about $20 \%$ [3]. Then, the electricity service company tried to make up for the losses by charging the consumers with high fees.

In general, the really reduced power loss causes more attention for utilities, because it decreases the efficiency of energy transfer to customers. Despite this, the loss of reactive (wattles) power is manifestly

${ }^{1}$ Faculty of Electrical and Computer Engineering, University of Engineering and Technology Peshawar, Pakistan. E-mail: irshad.hussain@uetpeshawar.edu.pk (Corresponding Author).

${ }^{2}$ Faculty of Information and Communication Technology, BUITEMS, Quetta, Pakistan.

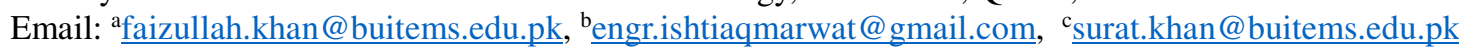

${ }^{3}$ Department of Electrical Engineering, National University of Computer and Emerging Sciences, Islamabad. Email: muhammad.saeed@nu.edu.pk

This is an open access article published by Mehran University of Engineering and Technology, Jamshoro under CC BY 4.0 International License. 
equally important. This is because the reactive power flow in the system must be sustained at a determined level in order to reach a sufficient voltage level. Therefore, reactive power can transmit actual power to customers through transmission and distribution lines.

Losses can be technical or non-technical. The technical loss comes from the nature and type of the load, the design of the electrical equipment, the poor maintenance of the system and the overload. Technical losses belong to the nature of the material and its resistance to the current dissipated in the form of heat dissipation. Technical losses are easily simulated and calculated $[4,5,9,10]$.

Non-technical losses include incorrect measurements, human errors during installation, management processes, and theft of electricity [10]. There are different technologies to reduce losses in distribution lines, such as bypass capacitors placement, load management, reconfiguration of network and incorporation of distributed power generation units into distribution system [2]. All of these techniques consist the inactive components of the circuit apart from the incorporation of distributed generation units involving active circuit elements. The integration of the capacitor layout technology and the distributed generation unit resulted in better voltage profile, but the integration reduction with distributed generation line loss was almost twice that of the capacitor arrangement $[6,11]$.

Distributed generation (DG) is a small amount local power production technology and can be integrated at various load levels (grid station, distribution line). In literature, there are other names such as Alternative Energy Systems 'Distributed Generations' (by North American countries) and 'Integrated Generations' (by British Americans) [1]. Its power delivering capacity ranges from a few kilowatts to several megawatts [6].

In order to integrate distributed generation into radial feeders, the following conditions are necessary. The system must be in the same phase, the system frequency must be the same, and the terminal voltage must be the same $[7,8,12]$. DG has a major impact on the network. These can be positive or negative, depending on the classification, type of DGs and their load location. The advantage of distributed generation include better quality of energy, better power supply, better voltage distribution, reduced environmental and safety issues, higher efficiency, and maximum utilization. The noumenon benefits of distributed generation are the reduction of electrical losses due to its closeness to the load has attracted the mental focus of researchers around the world [13].

Some of the disadvantage caused by DG consist of fluctuations in voltage, transient reconnection, and immoderate harmonic components that can cause serious problems to users of neighboring DG power supplies [14]. Distributed generation also produce the problem like over current protection, ferromagnetic resonance, insulation reduction, transformer connection and ground faults $[13,15]$. If installed in a proper manner distributed generation can improve customer satisfaction and network reliability. The size and position of the DG in the distribution system must be such that the incorporated DG and connection points do not transgress voltage curves, system losses, and do not cause coordination failures of existing systems $[16,17]$.

In general, DG incorporation causes a reduction in the flow of current is some part of feeder, which in turn reduces line loss. The amount of line loss depends on the flowing current in the feeder and the resistance of the line. Therefore, the losses can be minimized by minimizing the flow of current or resistance or even both. This paper focuses on the analysis of feeder loss reduction and improvement in the efficiency of the system by integrating different DG capacity in three radial distribution feeders at Bannu. We use this as a case study. Line loss calculation analyses and quantifies DG capacity through mathematics and ETAP.

In a nutshell the paper is organized in incremental order where, Section 2 presents a generic model of the system by incorporating various cases. Section 3 entailed the relevant calculation of the selected feeders and various system parameters like losses, Integration capacity and levels etc. have been incorporated by tabulating them in various tables as given in the preceding sections. 


\section{SYSTEM MODELING}

\subsection{Description of the Test Feeder}

To analyze the impact of DG on the feeder, three $11 \mathrm{kV}$ radial distribution feeders from $132 \mathrm{kV}$ grid station Bannu have been selected. Line losses of the selected feeders are calculated by considering various capacity DG's and then the selected feeders are designed and simulated in ETAP. The required data such as length, load etc. for simulating in ETAP and mathematical calculations was collected from the nearby WAPDA office. Line losses of the selected feeders are calculated before and after DG integration. They are sketched in Fig. 1.

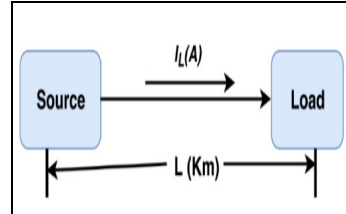

(a)

Fig. 1: Radial Distribution System (a) Before integration of DG (b) After integration of DG [12]

\subsection{DG Connection Scenario}

To analyze the impact of DG on selected feeder for line loss reduction, different capacity of DGs have been installed at fixed location of $75 \%$ from substation as given below, moreover Fig. 2 shows all these four cases on a graph.

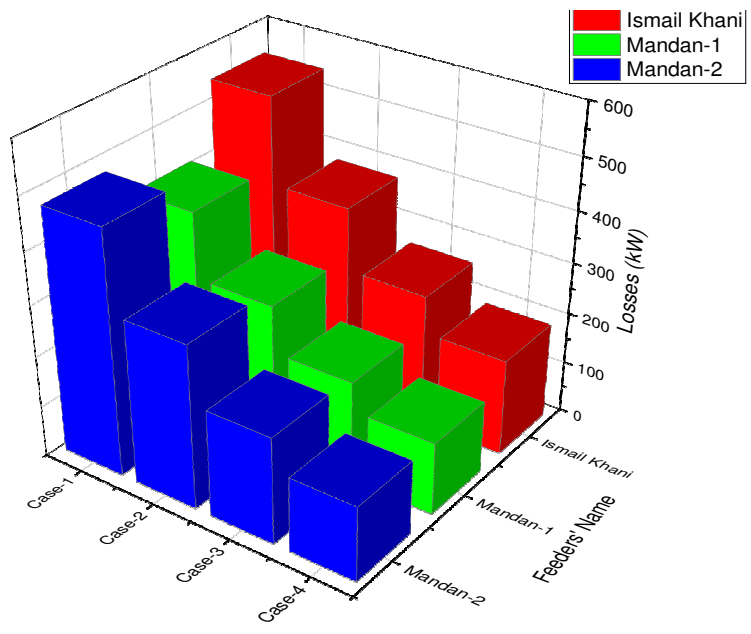

Fig. 2: Impact of DG Injection on Line Loss Reduction (For all four cases)
Case\# 01: Analysis of line loss before the DG integration where whole power is supplied by substation to the load.

Case\# 02: Analysis of line loss reduction after the DG integration which is providing $25 \%$ power supplied by the substation.

Case\# 03: Analysis of line loss reduction after the DG integration which is providing $50 \%$ power supplied by the substation.

Case\# 04: Analysis of line loss reduction after the DG integration which is providing $75 \%$ power supplied by the substation.

\section{FORMULATING ACTIVE/REACTIVE POWER AND LOSSES}

Mathematical calculation (for reducing the losses) are performed mainly in two steps i.e. 3.1) before DG integration and 3.2) after DG integration as mentioned below.

\subsection{Before Insertion of DG:}

The generic formula for line loss before integration of DG instrument is given by equation (1)

$\operatorname{LOSS}_{\mathrm{BD}}=\frac{\left(\mathrm{S}_{\mathrm{L}}^{*}\right)^{2}}{\left(\sqrt{3} \mathrm{~V}_{\mathrm{L}}\right)^{2}} \times \mathbf{r L}=\frac{\mathbf{r L}\left(\mathrm{P}_{\mathrm{L}}^{2}+\mathrm{Q}_{\mathrm{L}}^{2}\right)}{3 \mathbf{v}_{\mathrm{L}}^{2}}$

where, $\mathbf{L O S S}_{\mathbf{B D}}$ is the Net loss in the radial feeder before the commencement of DG, $\mathbf{W}$

The total real (i.e. active) power of the load is

$\mathbf{P}_{\mathrm{L}}=\sqrt{3} \mathbf{V}_{\mathrm{L}} \mathrm{I} \operatorname{Cos} \theta$

and the total reactive power of the load is

$\mathrm{Q}_{\mathrm{L}}=\sqrt{3} \mathrm{~V}_{\mathrm{L}} \mathrm{ISin} \theta$

\subsection{After the Insertion of DG:}

When DG is injected into radial distribution system, there happen two types of power losses as given by Equation (4) and Equation (5)

whereas, equation (4) represents losses from source to DGs while equation (5) shows the losses from DGs to 
load, on the lines.

$\operatorname{LOSS}_{\mathrm{STD}}=\frac{\mathrm{rG}\left(\mathrm{P}_{\mathrm{D}}^{2}+\mathrm{Q}_{\mathrm{D}}^{2}+\mathrm{P}_{\mathrm{L}}^{2}+\mathrm{Q}_{\mathrm{L}}^{2}-2 \mathrm{P}_{\mathrm{D}} \mathrm{P}_{\mathrm{L}}-2 \mathrm{Q}_{\mathrm{D}} \mathrm{Q}_{\mathrm{L}}\right)}{3 \mathrm{~V}_{\mathrm{L}}^{2}}$

$\operatorname{LOSS}_{\mathrm{DTL}}=\frac{\mathrm{r}(\mathrm{L}-\mathrm{G})\left(\mathrm{P}_{\mathrm{L}}^{2}+\mathrm{Q}_{\mathrm{L}}^{2}\right)}{3 \mathrm{~V}_{\mathrm{L}}^{2}}$

Moreover the total power loss can be calculated by adding the line losses that are occurring from source to the location of distributed generation and from distributed generation location to load as shown in equation (6).

$\mathrm{LOSS}_{\mathrm{AD}}=\mathrm{LOSS}_{\mathrm{STD}}+\mathrm{LOSS}_{\mathrm{DTL}}$

$\operatorname{LOSS}_{\mathrm{AD}}=\frac{\mathrm{rL}}{3 \mathrm{~V}_{\mathrm{L}}^{2}}\left[\mathrm{P}_{\mathrm{L}}^{2}+\mathrm{Q}_{\mathrm{L}}^{2}+\left(\mathrm{P}_{\mathrm{D}}^{2}+\mathrm{Q}_{\mathrm{D}}^{2}-2 \mathrm{P}_{\mathrm{D}} \mathrm{P}_{\mathrm{L}}-\right.\right.$

$\left.\left.2 Q_{D} Q_{L}\right) \frac{G}{L}\right]$

where,

$\mathrm{P}_{\mathrm{L}}$ Total active power of load, $\mathrm{W}$

$\mathrm{Q}_{\mathrm{L}}$ Total active power of load,VAR

$P_{D}$ Total active power of distributed generator, $W$

$Q_{D}$ Total reactive power of DG,VAR

\subsection{Losses in Selected feeders:}

The selected feeders in our case study are Ismail Khani, Mandan-1, and Mandan-2, Bannu. Active and reactive power are calculated from equation (2) and equation (3) respectively. Values of load, voltage and length of selected feeders are collected from respective grid stations. Losses are calculated by putting all the desired values in equation (1). The losses occurring in these feeders before integration of Distribution Generation are shown in Table 1.

\begin{tabular}{|c|c|c|c|}
\hline \multicolumn{4}{|c|}{ Table 1: Losses in the feeders without DG } \\
integration (Case-I) \\
\hline No. & Feeder Name & $\begin{array}{c}\text { Losses } \\
(\mathrm{kW})\end{array}$ & $\begin{array}{c}\text { Percentage } \\
\text { Losses }\end{array}$ \\
\hline 01 & $\begin{array}{c}\text { Ismail Khani } \\
(11 \mathrm{kV})\end{array}$ & 544 & $9.29 \%$ \\
\hline 02 & $\begin{array}{c}\text { Mandan-I } \\
(11 \mathrm{kV})\end{array}$ & 412 & $5.89 \%$ \\
\hline 03 & $\begin{array}{c}\text { Mandan-II } \\
(11 \mathrm{kV})\end{array}$ & 476 & $6.81 \%$ \\
\hline
\end{tabular}

The total loss after integration of DG into the radial distribution feeder is calculated by putting respective value in equation (6). Three different capacity of DG is considered i.e. $25 \%, 50 \%$ and $75 \%$ of the total real power. The total losses in these feeders after integration of different capacity of Distribution Generation are shown in Table 2.

\subsection{Feeder Modelling in ETAP:}

Electrical Transient Analysis Program (ETAP) software is used for the analysis of distribution system. In study we took three feeders Ismail Khani, Mandan1, Mandan-2 from $132 \mathrm{kV}$ substation located in Bannu district of Peshawar Electricity Supply Company (PESCO) region Pakistan. The data used for analysis is in the form of single line diagram starting from power transformer at substation till the load. The conductors and distribution transformers are modeled according to their rating in ETAP. The load connected with feeders is heterogeneous in nature as it is comprising of both, residential load and commercial load like domestic load, shopping plazas, industrial load, academic institutions and offices etc. Total number of distribution transformers including various capacities and length of each feeder are shown in Table 3.

\begin{tabular}{|c|c|c|c|c|c|c|c|}
\hline \multicolumn{8}{|c|}{ Table 2: Losses in the feeders, after the integration of DGs (Case-2, Case-3 \& Case-4) } \\
\hline \multirow{2nnnyyyy}{*}{ No. } & Feeder's & \multicolumn{3}{|c|}{ Losses (kW) } & \multicolumn{3}{c|}{ Percentage (Losses) } \\
\cline { 3 - 8 } & Name & Case-2 & Case-3 & Case-4 & Case-2 & Case-3 & Case-4 \\
\hline 01 & Ismail Khani & 378 & 258 & 187 & $6.45 \%$ & $4.41 \%$ & $3.19 \%$ \\
\hline 02 & Mandan-1 & 286 & 196 & 141 & $4.09 \%$ & $2.81 \%$ & $2.01 \%$ \\
\hline 03 & Mandan-2 & 319 & 208 & 146 & $4.57 \%$ & $2.97 \%$ & $2.09 \%$ \\
\hline
\end{tabular}

\begin{tabular}{|c|c|c|c|c|}
\hline \multicolumn{5}{|c|}{ Table 3: Test Feeders' Components and their Ratings } \\
\hline S.No. & Feeder & Power factor (\%) & No. of Transformers (11kV/440V) & Load (kVA) \\
\hline 01 & Ismail Khani & 96 & 149 & 6097 \\
\hline 02 & Mandan-1 & 94 & 108 & 7430 \\
\hline 03 & Mandan-2 & 94 & 92 & 7430 \\
\hline
\end{tabular}


Our main focus is on the analysis of line loss reduction with the integration of DG into a radial type distribution. The location of DG integration is fixed at $75 \%$ of the length of each feeder. The capacity of DG is varied over three different values: $\mathrm{PD}=25 \%$ of feeder load $(\mathrm{kW})$, which we named Case- 2 . $\mathrm{PD}=50 \%$ of feeder load $(\mathrm{kW})$, which we named Case- 3 and PD $=75 \%$ of feeder load $(\mathrm{kW})$ which we named Case- 4 , while scenario without integration of DG is named Case-1 throughout the research paper. The operating power factor of DG is same as that of the feeder.

The results show that, as the capacity of DG is increased, greater reduction in line losses occur. This is due to the fact that, active and reactive power to the load is delivered by DG. The DG decreases the amount of current that flows through the given feeder from the source (of power) to the position where a DG has been integrated in the system. The results of ETAP well matched with that of mathematical calculations, where all the three feeders are connected to a power transformer T1 (26MVA) and all the feeders are for usual distributed load.

\subsubsection{Simulation of feeder in ETAP before DG integration- Case 01:}

The losses associated with this case are mentioned in Table 5 and the SLD is given in Fig. 3.

\begin{tabular}{|c|c|c|c|c|}
\hline \multicolumn{5}{|c|}{ Table 4: DGs used for carryingout the research } \\
\hline$\underline{\text { S.No. }}$ & $\frac{\underline{\text { DG Rating }}}{(\mathrm{kW})}$ & $\underline{\text { Case-2 }}$ & $\underline{\text { Case-3 }}$ & $\underline{\text { Case-4 }}$ \\
\hline$\underline{01}$ & $\underline{\text { Ismail }}$ & $\underline{1463}$ & $\underline{2926}$ & $\underline{4390}$ \\
\hline$\underline{\text { Khani }}$ & $\underline{\text { Mandan-1 }}$ & $\underline{1746}$ & $\underline{3492}$ & $\underline{5238}$ \\
\hline$\underline{03}$ & $\underline{\text { Mandan-2 }}$ & $\underline{1746}$ & $\underline{3492}$ & $\underline{5238}$ \\
\hline
\end{tabular}

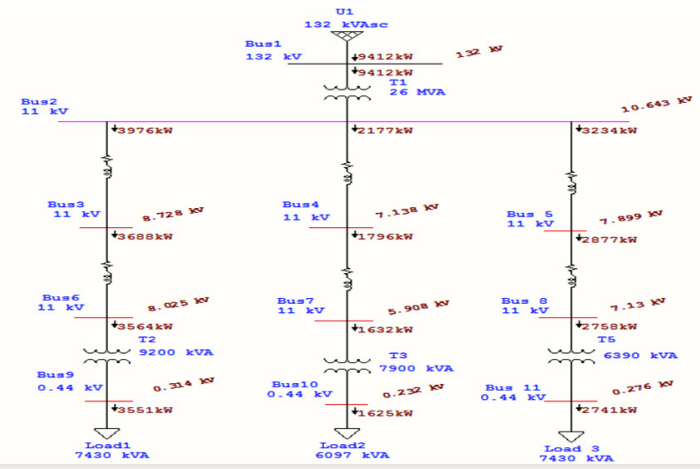

Fig. 3: Selected feeder before the integration of DG

\begin{tabular}{|c|c|c|c|c|}
\hline \multicolumn{5}{|c|}{ Table 5: Losses without DG Integration (Case 01) } \\
\hline $\begin{array}{c}\text { S. } \\
\text { No } \\
\cdot\end{array}$ & $\begin{array}{c}\text { Feeder's } \\
\text { Name }\end{array}$ & $\begin{array}{c}\text { Sending- } \\
\text { End Power } \\
\text { (BUS-2) } \\
\text { (kW) }\end{array}$ & $\begin{array}{c}\text { Receiving- } \\
\text { End Power } \\
\text { of Feeder } \\
\text { (kW) }\end{array}$ & $\begin{array}{c}\text { Real Power } \\
\text { Loss of the } \\
\text { feeder (kW) }\end{array}$ \\
\hline 01 & $\begin{array}{c}\text { Ismail } \\
\text { Khani }\end{array}$ & 2177 & 1632 & 544 \\
\hline 02 & $\begin{array}{c}\text { Mandan- } \\
1\end{array}$ & 3976 & 3564 & 412 \\
\hline 03 & $\begin{array}{c}\text { Mandan- } \\
2\end{array}$ & 3234 & 2758 & 476 \\
\hline
\end{tabular}

\subsubsection{Simulation of feeder in ETAP after $25 \%$ DG integration- Case 02:}

The suggested DG for our case is Wind Turbine Generator (WTG) of type-5. Such turbine consists of a typical WTG variable-speed drive train which is further connected to a torque/speed converter coupled with a synchronous generator. The torque/speed converter changes the variable speed of the rotor shaft to a constant output shaft speed. The closely coupled synchronous generator, operating at a certain fixed speed (corresponding to grid frequency i.e. $49.5 \mathrm{~Hz}-$ $50.5 \mathrm{~Hz}$ ), can then be directly connected to the grid through a synchronizing circuit breaker. This approach requires speed and torque control of the torque/speed converter along with the typical voltage regulator (AVR), synchronizing system, and generator protection system inherent with a grid-connected synchronous generator.

The major advantage of using this type of system is that it requires, a small amount power injected into the rotor circuit which can effectively control a large amount of power in the stator circuit. Moreover, a great deal of control of the output is available with the presence of a set of converters that typically are only $30 \%$ of the rating of the machine. In addition to the real power that is delivered to the grid from the generator's stator circuit, power is delivered to the grid through the grid-connected inverter when the generator is moving faster than synchronous speed. The typical circuit of such system could be found in Fig. 4.

Behavior of Type-5 system during short circuit-- Type 5 WTGs exhibit typical synchronous generator behavior during grid short circuits. Generator contribution to grid faults can be calculated from the machine constants obtainable from the generator 
manufacturer. Fault current contribution for line to ground faults will depend on the type of generator grounding used. Typical generator fault current contribution can range from 4 to more times rated current for close-in bolted three-phase faults.

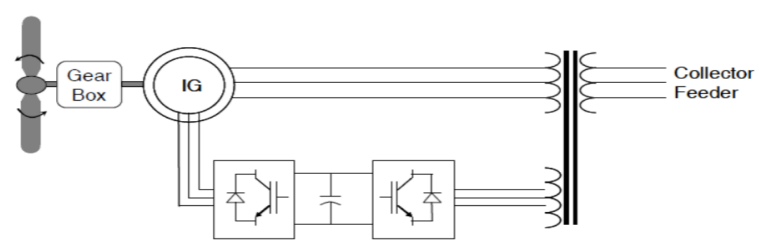

Fig. 4: Circuit of a Typical Type-5 WTG System

Fig. 5 shows the DG integration of $25 \%$ at $75 \%$ length of the feeder. The ratings of DG for Mandan-1, Ismail Khani and Mandan-2 are 1746, 1463 and 1746kW respectively. Moreover, it can be clearly seen that the active power losses are reduced after DG integration.

\subsubsection{Simulation of feeder in ETAP after $50 \%$ DG integration- Case 03:}

Now in Fig. 6 the capacity of DG is increased to $3492 \mathrm{~kW}, 2926 \mathrm{~kW}$ and $3492 \mathrm{~kW}$ for Mandan-1, Ismail Khani and Mandan-2 respectively. As the DG rating is increased the active power losses are further reduced.

\subsubsection{Simulation of feeder in ETAP after $75 \%$ DG integration- Case 04:}

Fig. 7 is the case where the DG rating is further increased to $75 \%$ of the load. The active power losses in the feeder are further reduced, as shown Table 8.

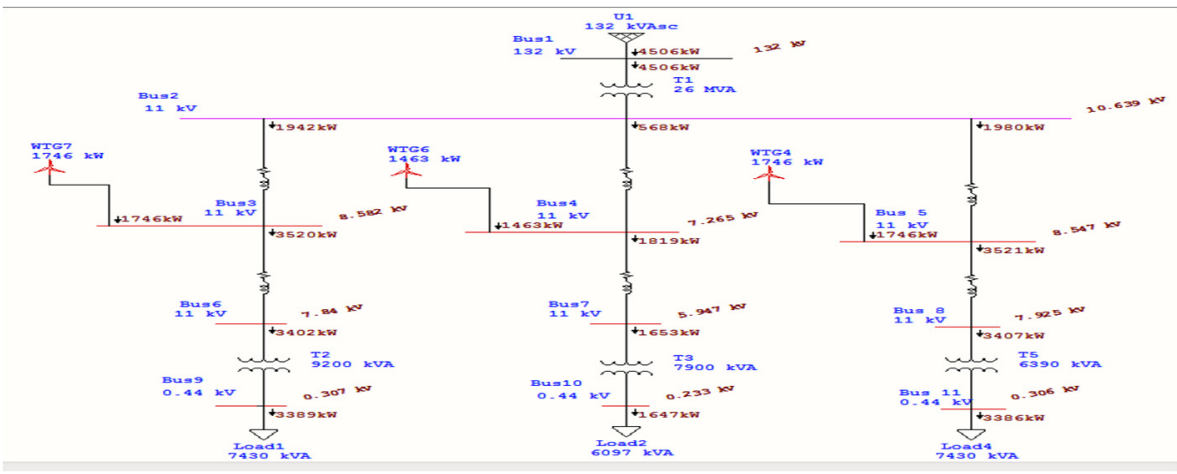

Fig. 5: Selected Feeder at 25\% Integration Level (Case: 02)

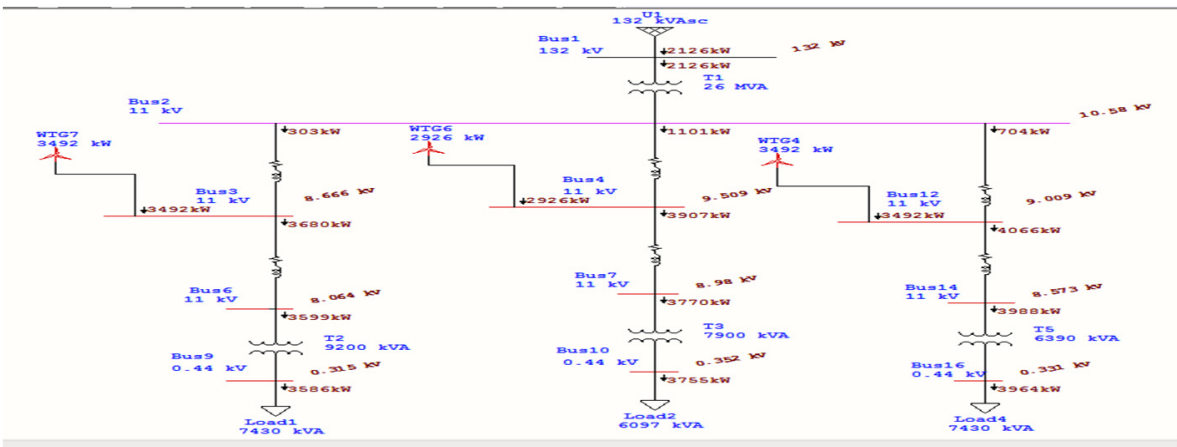

Fig. 6: Integration Level of 50\% (For the Selected Feeder) (Case: 03)

\begin{tabular}{|c|c|c|c|c|c|}
\hline \multicolumn{6}{|c|}{ Table 6: Losses after 25\% of DG Integration (Case 02) } \\
\hline Sr. No. & Feeders Name & BUS-2 (kW) & $\begin{array}{c}\text { Loss from Bus-2 to } \\
\text { DG }(\mathrm{kW})\end{array}$ & $\begin{array}{c}\text { Loss from DG to load } \\
(\mathrm{kW})\end{array}$ & Total loss (kW) \\
\hline 01. & Ismail Khani & 568 & 212 & 166 & 378 \\
\hline 02. & Mandan-1 & 1942 & 168 & 118 & 286 \\
\hline 03. & Mandan-2 & 1980 & 205 & 114 & 319 \\
\hline
\end{tabular}




\begin{tabular}{|c|c|c|c|c|c|}
\hline \multicolumn{7}{|c|}{ Table 7: Losses after 50\% of DG Integration (Case 03) } \\
\hline Sr. No. & Feeders Name & $\begin{array}{c}\text { BUS-2 } \\
(\mathrm{kW})\end{array}$ & $\begin{array}{c}\text { Loss from Bus-2 to } \\
\text { DG }(\mathrm{kW})\end{array}$ & $\begin{array}{c}\text { Loss from DG to } \\
\text { load }(\mathrm{kW})\end{array}$ & $\begin{array}{c}\text { Total loss } \\
(\mathrm{kW})\end{array}$ \\
\hline 01. & Ismail Khani & 1101 & 120 & 137 & 257 \\
\hline 02. & Mandan-1 & 303 & 115 & 81 & 196 \\
\hline 03. & Mandan-2 & 704 & 130 & 78 & 208 \\
\hline
\end{tabular}

\begin{tabular}{|c|c|c|c|c|c|}
\hline \multicolumn{7}{|c|}{ Table 8: Losses after 75\% of DG integration (Case 04) } \\
\hline S.No. & $\begin{array}{c}\text { Feeder } \\
\text { Name }\end{array}$ & $\begin{array}{c}\text { BUS-2 } \\
(\mathrm{kW})\end{array}$ & $\begin{array}{c}\text { Loss from Bus-2 } \\
\text { to DG }(\mathrm{kW})\end{array}$ & $\begin{array}{c}\text { Loss from DG to load } \\
(\mathrm{kW})\end{array}$ & $\begin{array}{c}\text { Total Loss } \\
(\mathrm{kW})\end{array}$ \\
\hline 01. & $\begin{array}{c}\text { Ismail } \\
\text { Khani }\end{array}$ & 101 & 83 & 102 & 185 \\
\hline 02. & Mandan-1 & 1101 & 64 & 92 & 156 \\
\hline 03. & Mandan-2 & 314 & 70 & 74 & 144 \\
\hline
\end{tabular}

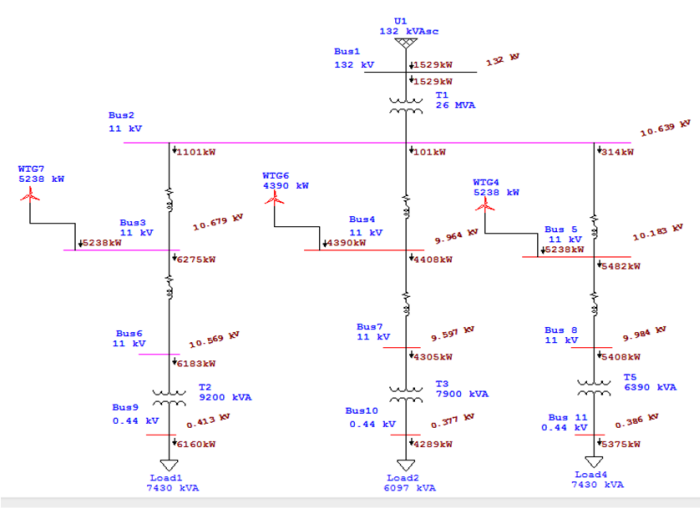

Fig. 7: 75\% Integration in The Selected Feeder (Case: 04)

\section{EFFICIENCY}

Efficiency is the measure of useful work of a system, which is generally represented by $\eta$. In most of the cases it is the ratio of an output quantity to the input quantity of a system as shown in Equation (7), however calculating efficiency for electrical power system (especially for distribution system) is not pretty simple because one has to find the losses or should know the incoming power (to a feeder) and outgoing power (from the feeder) or the sending power of the feeder/distribution line and cumulative power received at the load (centers). In Equation (7) $\mathrm{P}_{\mathrm{o}}$ means the power received to the load centers or the amount of power reaching the receiving end whereas, $P_{i}$ is the amount of power fed at the sending end. We've the values of $\mathrm{P}_{\mathrm{o}}$ however the losses for Case- 1 have been obtained via equation (1) while for Case-2, Case-3 and Case- 4 the losses are being obtained by putting the respective values in equation (4), equation (5) and equation (6). After that the formula used in equation (7) is used for finding the corresponding values of

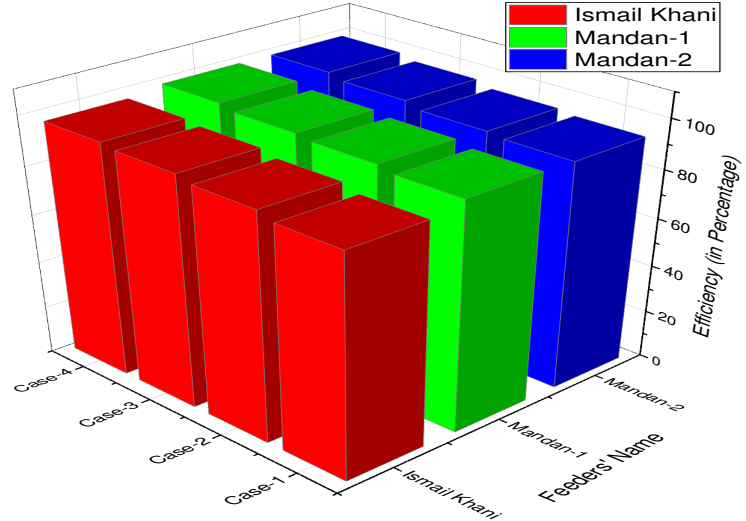

Fig. 8: Impact of DG on Efficiency

efficiency of each feeder for each individual case.

$\eta=\frac{P o}{P i} \times 100=\frac{P o}{P o+\text { Losses }} \times 100$

\section{CONCLUSION}

In this paper we incorporated reduction in line losses for a radial distribution system, with a distributed generator injected in the system at certain point. It is obvious from the outcomes that deployment of DG has reduced line losses. Furthermore it implies that increase in DG integration guarantees the line loss reduction in accordance with load rating. The DG integration also depends upon frequency of synchronization, phase and terminal voltage. However the rating of DG is mainly concerned with the position and feeder load. These factors should be analyzed and selected carefully for line loss reduction. The Integration of a DG unit into a given distribution system resulted in line loss reduction in radial distribution system. The same technique could be probed for efficient utilization for a combination of dispersed generation system and radial feeder.

\section{Mehran University Research Journal of Engineering and Technology, Vol. 40, No. 1, January 2021 [p-ISSN: 0254-7821, e-ISSN: 2413-7219]}




\begin{tabular}{|c|c|c|c|c|c|}
\hline \multicolumn{6}{|c|}{ Table 9: Effect of DG Integration on the Efficiency of System } \\
\hline S. No. & Feeders' Name & Case-1 & Case-2 & Case-3 & Case-4 \\
\hline 01. & Ismail Khani & $91.5 \%$ & $93.9 \%$ & $95.8 \%$ & $96.9 \%$ \\
\hline 02. & Mandan-1 & $94.4 \%$ & $96.1 \%$ & $97.3 \%$ & $99.02 \%$ \\
\hline 03. & Mandan-2 & $93.9 \%$ & $95 \%$ & $97.1 \%$ & $99 \%$ \\
\hline
\end{tabular}

\section{ACKNOWLEDGMENT}

The authors would like to thank the anonymous reviewers who improved the quality of this manuscript by their valuable comments.

\section{REFERENCES}

[1] Thomas A., Andersson G., Söder, L., "Distributed generation: a definition", Electric Power Systems Research, Vol. 57, No. 3 195-204, 2001.

[2] Irshad, Aamir, Ibrar, Khan N., Riaz M., "Reliable and Secure Advanced Metering Infrastructure for Smart Grid Network", Proceedings of the International Conference on Computing, Electronic and Electrical Engineering (ICE Cube), Quetta, pp. 1-6, 2018.

[3] Caicedo N. G., Lozano C.A., Díaz J.F., Rueda C., Gutiérrez G., Olarte C., "Loss reduction in distribution networks using concurrent constraint programming", Proceedings of the International IEEE Conference on Probabilistic Methods Applied to Power Systems, pp. 295-300, 2004.

[4] Atteya I.I., Ashour H., Fahmi N., Strickland D., "Radial distribution network reconfiguration for power losses reduction using a modified particle swarm optimization", CIRED-Open Access Proceedings Journal, Vol. 2017, No. 1, $2505-$ 2508, 2017.

[5] Jena S., Chauhan S., "Solving distribution feeder reconfiguration and concurrent DG installation problems for power loss minimization by multi swarm cooperative PSO algorithm", Proceedings of the IEEE/PES Transmission and Distribution Conference and Exposition (T\&D), pp. 1-9, 2016.

[6] Biricik S., Özerdem Ö. C., "A method for power losses evaluation in single phase transformers under linear and nonlinear load conditions", Przeglad Elektrotechniczny (Journal of Electrical Review), Vol 87, No. 12, 2011.

[7] Amoiralis E.I., Tsili M.A., Antonios G. K.,
"Power transformer economic evaluation in decentralized electricity markets", IEEE Transactions on Industrial Electronics, Vol. 59, No. 5, 2012.

[8] Agüero J.R., "Improving the efficiency of power distribution systems through technical and nontechnical losses reduction", Proceedings of the Transmission and Distribution Conference and Exposition, pp. 1-8. IEEE, May 2012.

[9] Amoiralis E. I., Tsili M.A., Antonios G. K., "Economic evaluation of transformer selection in electrical power systems", Proceedings of the International Conference on Electrical Machines, pp. 1-5, IEEE, 2010.

[10]Dalila M. S., Khalid M. N., Shah M., "Distribution transformer losses evaluation under non-linear load", Proceedings of the Australian Universities Power Engineering Conference (AUPEC), pp. 1-6. IEEE, 2009.

[11] Bodapatla K.S., Inamdar H.P., "Loss reduction by optimal placement of distributed generation on a radial feeder", ACEEE International Journal on Electrical and Power Engineering, Vol. 2, No. 1, pp. 24-29, 2011.

[12] Khoa Dang T.Q., Binh P. T. T., Tran H. B., "Optimizing location and sizing of distributed generation in distribution systems", Proceedings of the PES Power Systems Conference and Exposition, pp. 725-732. IEEE, 2006.

[13]Dondi P., Bayoumi D., Haederli C., Julian D., Suter M., "Network integration of distributed power generation", Journal of Power Sources, Vol. 106, No. 1-2, p-p: 1-9, 2002.

[14] Parizad A., Khazali A., Kalantar M., "Optimal placement of distributed generation with sensitivity factors considering voltage stability and losses indices", Proceedings of the 18th Iranian Conference on Electrical Engineering, pp. 848-855, IEEE, 2010.

[15] Olatoke A., Mohamed K. D., "A study of the impact of Distributed Generation on power quality", Proceedings of the 47th International Mehran University Research Journal of Engineering and Technology, Vol. 40, No. 1, January 2021 [p-ISSN: 0254-7821, e-ISSN: 2413-7219] 
Universities Power Engineering Conference (UPEC), pp. 1-5. IEEE, 2012.

[16] Barker, P.P., Robert W. D., "Determining the impact of distributed generation on power systems. I. Radial distribution systems", Proceedings of the Power Engineering Society Summer Meeting, Vol. 3, pp. 1645-1656. IEEE, 2000.
[17] Sailaja Ch V.S,S, Prasad P.V.N., "Determination of optimal distributed generation size for losses, protection Co-ordination and reliability Evaluation Using ETAP", Proceedings of the Biennial International Conference on Power and Energy Systems: Towards Sustainable Energy (PESTSE), pp. 1-6. IEEE, 2016. 